\title{
The Future of Artificial Intelligence in International Healthcare: An Index ${ }^{1}$
}

\author{
Julia M. Puaschunder ${ }^{1,2}$ \\ ${ }^{1}$ The New School, Department of Economics, 6 East $16^{\text {th }}$ Street, 9 $9^{\text {rd }}$ floor 89, New York, NY 10003, USA, \\ Julia.Puaschunder@newschool.edu, T 001212229 5700,F001212229 5724,www.juliampuaschunder.com \\ ${ }^{2}$ Columbia University, Graduate School of Arts and Sciences, Julia.Puaschunder@columbia.edu, http:/ / blogs.cuit.columbia.edu/jmp2265
}

\begin{abstract}
The currently ongoing COVID-19 crisis has challenged healthcare around the world. The call for global solutions in international healthcare pandemic crisis and risk management has reached unprecedented momentum. Digitalization, Artificial Intelligence (AI) and big data-derived inferences are supporting human decision making as essential healthcare enhancements as never before in the history of medicine. In today's healthcare sector and medical profession, AI, algorithms, robotics and big data are used for monitoring of large-scale medical trends by detecting and measuring individual risks based on big datadriven estimations. This article provides a snapshot of the current state-of-the-art of AI, algorithms, big dataderived inferences and robotics in healthcare but also medical responses to COVID-19 in the international arena. International differences in the approaches to combat global pandemics become apparent serving as interesting case study on how to avert global pandemics successfully with AI in the future. Empirically, the article answers what countries have favourable conditions to provide AI solutions for global healthcare and pandemic crises monitoring and alleviation when compared over the entire world? First, an index based on internet connectivity - as a proxy for digitalization and AI advancement- as well as Gross Domestic Product (GDP) - as indicator for economic productivity - is calculated to outline global pandemic healthcare solution innovation hubs with economic impetus around the world. The parts of the world that feature internet connectivity and high GDP are likely to lead on AI-driven big data monitoring insights for pandemic prevention. When comparing countries worldwide, AI advancement is found to be positively correlated with anti-corruption. AI thus springs from non-corrupt territories of the world. Second, a novel anti-corruption artificial healthcare index is therefore presented that highlights those countries in the world that have vital AI growth in a non-corrupt environment. These non-corrupt AI centres hold comparative advantages to lead on global artificial healthcare solutions against COVID-19 and serve as pandemic crisis and risk management innovators of the future. Anti-corruption is also positively related with better general healthcare. Therefore, finally, a third index that combines internet connectivity, anti-corruption as well as healthcare access and quality ${ }^{1}$ is presented. The countries that score high on AI, anti-corruption and healthcare excellence are presented as ultimate world-leading, innovative global pandemic alleviation centres. The advantages but also potential shortfalls and ethical cliffs in the novel use of monitoring Apps, big data inferences and telemedicine to prevent pandemics are discussed.
\end{abstract}

KEYWORDS: Access to healthcare, Advancements, AI-GDP Index, Apps, Artificial Intelligence (AI), Coronavirus, Corruption-free maximization of excellence and precision, Corruption Perception (CPI)-Global Connectivity (GCI) Index, Corruption Perception (CPI)-Global Connectivity (GCI)-Healthcare Index COVID-19, Decentralized grids, Economic growth, Healthcare, Human resemblance, Humanness, Innovation, Market disruption, Market entrance, Pandemic, Rational precision, Social stratification, Supremacy, Targeted aid, Telemedicine

\section{Artificial Intelligence (AI)}

AI is "a broad set of methods, algorithms, and technologies that make software 'smart' in a way that may seem human-like to an outside observer" (Noyes 2016). The Oxford Dictionary defines AI as "the theory and development of computer systems able to perform tasks normally requiring human intelligence, such as visual perception, speech recognition, decision-making, and translation between languages." AI describes the capacity of a computer to perform the tasks commonly

\footnotetext{
${ }^{1}$ The author thanks Professor Director Susan Rose-Ackerman for most excellent lectures on 'Corruption, Economic Development \& Democracy' at Yale Law School and online due to COVID-19 as well as the participants of the respective class for most helpful share of expertise and interesting discussions.
} 
associated with human beings. It includes the ability to review, discern meaning, generalize, learn from past experience and find patterns and relations to respond dynamically to changing situations (Gowling WLG 2019). AI is perceived as the sum of different technological with currently developing regulation (Dowell 2018). Machine learning are computational algorithms that learn from data in order to derive inferences.

\section{Artificial Intelligence international leadership}

AI leadership appears to develop foremost in Europe, North America and China. Together, the United States, China and the European Union represent over 93 percent of total AI private equity investment from 2011 to mid-2018. Of those investments, 8 percent occurred in Europe, 30 percent in China and about 70 percent in the United States. Start-ups in Israel (3 percent), Japan and Canada (1.6 percent) also played a role (OECD, 2019). Over the years AI has also grown in qualitative terms, with widespread applications in transportation, agriculture, finance, marketing and advertising, science, healthcare, criminal justice, security as well as virtual reality applications (OECD, 2019).

The legal and regulatory status of AI is still developing in jurisdictions around the world. The United Nations (UN) agencies and regional organizations report internationally varying contemporary guidelines, ethics codes and action statements. The digital era governance and democracy features data-driven security in central and local governments through algorithmic surveillance. Open source data movements can become a governance regulation tool. In the sharing economy, public opinion and participation in the democratic process has become dependent on data literacy. According to the Library of Congress, most countries in the Western world aspire to embrace the advantages of $\mathrm{AI}$ and become leaders in the field through developing national AI or digital strategies and action plans.

The OECD (2019) hosted a Council on Artificial Intelligence in the first half of 2019 to set international AI standards on a global level. The United Nations opened a Centre on Artificial Intelligence and Robotics within the UN system in The Hague, The Netherlands in 2017 . The International Telecommunication Union worked with more than 25 other UN agencies to host the "AI for Good" Global Summit. The UNESCO has launched a global dialogue on the ethics of AI due to its complexity and impact on society and humanity. In 2017 the International Organization for Standardization (ISO) and the International Electrotechnical Commission (IEC) created a joint technical committee to develop information technology standards for business and consumer applications on AI standards. Labor unions have also defined key principles for ethical AI.

\section{Artificial Intelligence in healthcare}

$\mathrm{AI}$ and robotics supported medical assistance and scientific discovery have increased steadily within the last decades foremost in the areas of big data analytics, telemedical solutions and robotics. The big data revolution and hierarchical modelling advancements as well as computational power are starting to dominate an inference-driven access to healthcare and medical prevention. Therapeutic data-driven information and self-monitoring, as well as patient and claims data to recommend treatments and estimate outcomes have leveraged to unprecedented sophistication. With the growth of scientific evidence derived from big data, AI helps analyze health trends to guide on general healthcare (Groebel 2019). Online App-administered tracking provides a complete view of the patient journey over time, covering the spectrum from early disease state, to management of health goals, therapeutic choices and therapy-specific outcomes, and future health goals (Puaschunder 2019a, b).

In recent years, there has been tremendous growth in the range of medical information collected, including clinical, genetic, behavioral and environmental data. As never before in history, improvements in data generation, storage and analysis coupled with unprecedented computational power and statistical means has resulted in optimal conditions for large-scale data collection and processing advancements. Growth of genomic sequencing databases but also widespread awareness 
and implementation of electronic health recording have improved the nature and quality of accessible preventive medicine.

Every day, healthcare professionals, biomedical researchers and patients produce vast amounts of data from an array of devices. These include electronic health records (EHRs), genome sequencing machines, high-resolution medical imaging, smartphone applications and ubiquitous sensing, as well as Internet of Things (IoT) devices that monitor patient health (OECD 2015). Through machine learning, algorithms and unprecedented data storage and computational power, AI technologies have most advanced abilities to gain information, process it and give a well-defined output to the end-user. Daily monitoring creates big data to recognize behavioral patterns' relation to health status in order to predict with highest mathematical precision based on big data capturing large-scale samples. AI thereby enables to analyze the relation between prevention and treatment and patient outcomes in all stages of diagnosis, treatment, drug development and monitoring, personalized medicine, patient control and care. Advanced hospitals are looking into AI solutions to support and perform operational initiatives that increase precision and cost effectiveness. Medical decision making has been supported through predictive analytics and general healthcare management technology. The wealth of electronic health records has excelled digitalized diagnosis and prevention of diseases and disease outbreak control (Puaschunder 2019e). Health risk early warning systems through data collected via mobile Apps but also pandemic spread visualized via google search mapping analytics are the most recent advancements based on big data, large-scale mapping sophistication and computation control.

Information and Communication Technologies (ITC) have increased the possibilities of telemedicine. Telehealth enables remote and instant monitoring and preventive control but also instant emergency outreach and remote diagnosis based on large-scale data-driven knowledge generation and decentralized healthcare access. Network connectivity allowing telemedical care grants access to affordable healthcare around the globe in a cost-effective way. The medical world has become flat and international development crisis management has profited from data-driven prevention. Instant messaging has opened the gates for remote access to affordable diagnostics. Networking data sharing capacities have reached unprecedented density and sophistication. Healthrelated data from personal self-diagnosis devices coupled with low-cost generation of big data and patient-led monitoring makes data-driven quality care more accessible in remote areas and developing nations. Self-led monitoring and remote diagnosis coupled with machine learning mining of big data and algorithmic decision making are continuously meant to grant access to affordable and excellent healthcare around the globe in the future. Clinical decision support systems are expected to advance in the near future with $5 \mathrm{G}$ technologies arising, which will boost prognostic capacities.

In the future, $\mathrm{AI}$ is believed to revolutionize healthcare in areas such as surgery, radiology and cancer detection with improved healthcare delivery and patient experience. Some of the most recent advancements include self-monitoring through diagnostic tattoos that change color when certain medical conditions - such as for instance diabetes or cancer - occur. The development of programmable cells that destroy diseases naturally and internally are cutting-edge developments of the future on the intersection of self-determined prognosis led by algorithmic big-data derived insights (Knapton 2016). Radiology and imaging benefit from computer-guided and big dataenhanced capacities to diagnose and predict future outcomes concurrently. Robotics have entered the medical field as assisted body parts or surgery devices as well as support for disabled and patient care assistance, automated nursery and mental health stabilizers.

\section{Future artificial medical care and economic growth}

The healthcare AI market is expected to surge by a compound annual growth rate of 50.2 percent from now until 2025 based on market innovations (ReportLinker 2018). The use of AI is predicted to improve the prevention of diseases, accuracy of diagnoses and predictions on treatment plan outcomes. AI innovations offer benefits of rational precision and human resemblance, targeted aid, corruption-free 
maximization of excellence and precision. Hospitals and healthcare provider segments are expected to hold the largest size of AI in healthcare market in terms of end user. A few major factors responsible for the high share of the hospitals and providers segment include a large number of applications of AI solutions across provider settings, the ability of AI systems to improve care delivery and patient experience while bringing down costs as well as the growing adoption of electronic health records by healthcare organizations. Moreover, AI-based tools, such as voice recognition software and clinical decision support systems, help streamline workflow processes in hospitals at lower cost with improved care delivery and enhanced patient experience (ReportLinker 2018). Utilizing the predictive power of big data has perpetuated the effectiveness and efficiency in the healthcare sector.

A 2017 Accenture Research and Frontier Economics report of economic growth rates of 16 industries concluded that AI has the potential to boost profitability on average by $38 \%$ by 2035 (Gowling WLG 2019). Machine learning's ability to collect and handle big data, and its increasing adoption by hospitals, research centers, pharmaceutical companies and other healthcare institutions, are expected to fuel growth in the healthcare sector with hospitals and provider segments holding the largest end user market for AI solutions (Lagasse 2018). Outsourcing monitoring to patience and electronic recording devices but also tapping into the wealth of expert knowledge generated through big data helps classical human medical doctors and healthcare agents, who benefit from freed capacities for creative decision making and expert advice giving. In addition, advances in 3D printers may soon make it possible to substitute healthcare provision closer to the consumer, where the manufacturing process is simplified thanks to the reproduction of models.

The adoption of electronic health records by healthcare organizations and the outsourcing of health monitoring by novel personal care products - such as routine check-up medical tools and wearable devices - is further believed to better service quality and eventually bring down costs via improved prevention through higher frequency of checks at lower costs. Advanced computing power and the declining cost of hardware are other key factors in the projected market growth at lowering costs (Lagasse 2018). The growing adoption of applications - such as patient-data and risk analysis, lifestyle management and monitoring, and mental health - is further propelling technology in the market (Puaschunder, 2019b; ReportLinker 2018).

Healthcare has never been as individually-targeted and accessible as today. User selfreporting allows instant information generation and in-depth knowledge retrieval. Digital consultant apps enable medical consultation based on personalized medical history record analyses and common medical knowledge derived from big data inferences. Virtual nursing assistants are predicted to become more common to perform targeted patient aid that can run $24 / 7$ at most efficient levels.

Technological development is bringing production and manufacturing closer to the end user in the sharing economy. Decentralized medical aid allows tapping into information closely. Remote communities thereby benefit from equal, easy and cheap access to medical aid. Information share among neighbors helps overcome shortages and enables fast-paced aid cheaper and more democratically-distributed. Geopolitically the individual becomes more independent from centralized medical structures.

Today technology plays an important role to help analyze and identify actionable insights derived from a multitude of accessible data sources. The medical profession shifts towards precision medicine using a variety of complex datasets such as a patient's health records, physiological reactions and genomic data (OECD, 2019). With medical literature doubling every three years, also the pharma industry now has access to unprecedented amounts of scientific data that allows a cartography of medical device distribution to help overcome bottlenecks and fraud while protecting patient privacy (Groebel 2019). Once tagged and compiled, AI tools that employ natural language processing help mine the data for community health status monitoring and pandemic outbreak tracking. All these AI-led opportunities to gather actionable insights lead to strategic data-driven interventions on medical prevention and health crisis management excellence. While data collection is easier than ever, proper usage of linked data is and will be a key factor for productivity, quality and accessibility of AI-driven applications. The core promise of data-driven 
solutions is to collect data at a density that is not feasible for humans and identify patterns humans cannot grasp.

Since AI in healthcare is currently utilized mainly to aggregate and organize data - looking for trends and patterns and making recommendations - a human component that is creative, cognitively highly flexible and compatible with AI sources is still needed (Puaschunder 2019d, e; ReportLinker 2018). Rather than replacing human medical doctors and staff, AI is therefore believed to support medical doctors and nurses alike and help on decision making predicaments, as burn out prevention by aiding on cognitive load capacity constraints with supremacy of excellence and precision (Puaschunder 2019d, e; Puaschunder \& Gelter 2019). Radiology is a good example why technology often will not replace humans, instead giving them better tools (Hosny, Parmar, Quackenbush, Schwartz \& Aerts 2018; Pakdemirli 2019).

Decentralized information collection and storage grid as well as technological diversified data collection means are expected to revolutionize the healthcare sector. Thereby healthcare providers make sense of vast amounts of data to reach the optimum patient health or recovery potential. Decentralized grids also open novel opportunities of monitoring and measuring, as information can be tracked and linked directly to the scientific and patient impact they are having, including knowing if the expert visited the medical portal, opened an email, or requested additional information. Novel mapping tools can translate local search results and crowd media use into visible information display so it becomes more accessible in a broader way. Decentralized crisis management applications of AI and machine learning already range from data-driven assistance in crisis management and control to battling hunger and poverty as well as forced migration.

With the currently ongoing COVID-19 crisis, we may see a further development of an effective big data-driven crisis response ecosystem in public health pandemic early warning and disease transmission monitoring systems. Targeted aid can form a grid of medical specialists to work concurrently in the diagnosis of a patient. Integration of fragmented diagnosis and treatment results coupled with self-monitoring devices collecting data at hand on a constant basis are viewed as future medical necessities. An as such integrated diagnostic process fosters personalized treatment. Data integrated grids can also combat fragmentation of different help groups and foster information flow between field workers responding to crises.

Intriguing, yet under-researched, appears that AI, robots and algorithms differ from human healthcare providers by holding the potential to be less prone to corruption than human counterparts. If programmed to follow an ethical imperative, AI and robots being without selfenhancing profit-maximizing goals promises to grant healthcare free from any corruption, bribery or irrational price margins.

\section{Corruption}

Breeding in collective experiences in the pertaining societal networks and social norms, corruption determines economic development and the state of democracy around the world (Bardhan 2016; Davis \& Trebilcock 2008; Fisman \& Miguel 2007; Rose-Ackerman \& Palifka 2016). Corrupt institutional structures have been associated with poverty and hindered international development (Human Development Report, 2019). Governmental revenues derailed through corruption weakens public financial management for the establishment, procurement and maintenance of collective goods (Campos \& Pradhan, 2007; http://www.resourcegovernance.org/). Corruption erodes the regulatory impact and the provision of public services ranging from medical care, education, energy, transportation and environmental protection (Campos \& Pradhan, 2007; Rose-Ackerman \& Palifka, 2016; Rose-Ackerman $\&$ Tan, 2014). Corruption has many faces: organized crime, illegal business, bribery, non-meritocratic placements and nepotism, tax havens, voting to name a few (Alt \& Lassen, 2012; Charron, Fazekas \& Lapuente, 2016; Gordon, 2009; Holmes, 2007; Johannesen \& Zucman, 2014; Klumpp, Mialon \& Williams, 2016; http://www.globalshellgames.com/; https://eiti.org/). Corruption is prevalent in territories with missing accountability and rule of law (Agerberg 2019; http://www.ti-defence.org/). International efforts to combat corruption include advancements in international treaties, governmental 
accountability and whistleblower protection (http://www.whistleblower.org), transparency, national laws against foreign-induced corruption, national security and peace-building (Boucher et al., 2007; Hite-Rubin, 2015; Le Billon, 2003; McLean, 2012; Rose-Ackerman \& Lagunes, 2015; Vlasic \& Atlee, 2012). ${ }^{2}$ Anti-corruption reform is likely to stem from the international community fostering corruption prevention, ${ }^{3}$ corporate watch, ${ }^{4}$ consumer action, ${ }^{5}$ social and ethical accountability, ${ }^{6}$ humanitarian accountability, ${ }^{7}$ international development ${ }^{8}$ and integrity action ${ }^{9}$ (Davis, 2019; Cooley \& Sharman, 2015; Engel, Ferreira Rubio, Kaufmann, Lara Yaffar, Londoño Saldarriaga, Noveck, Pieth \& RoseAckerman, 2018; Rose-Ackerman \& Carrington, 2013). ${ }^{10}$

Corruption in the digital age is still an area that demands for research to foster our understanding of the interrelation of corruption and AI-driven innovation. Institutional corruption in the digital age is a fairly low understood area that remains in qualitative case study attempts foremost in the political domain (Ackerman, 2020). A quantification of the relation of AI-led growth and corruption is - to this day - missing; yet highly relevant during this unprecedented time of $\mathrm{AI}$ in healthcare and digital governance.

\section{Artificial Intelligence in healthcare in the international arena during COVID-19}

The currently ongoing COVID-19 crisis increased attention to the potential of AI in healthcare as a pandemic prevention tool around the globe. COVID-19 unleashed the online healthcare tech world. On a flat globe, data traffic exploded. ${ }^{11}$ A multi-tasking online workforce ${ }^{12}$ gained global outreach $^{13}$ and flexibility in digitalization cutting red tape (Puaschunder 2019a; Wright 2020). Health apps (MedicalFuturist 2020) target at preventing COVID. Bluetooth-tracking ${ }^{14}$ of medical devices ${ }^{15}$ helps overcome bottlenecks and fraud while protecting privacy. ${ }^{16}$ Telemedicine cured remotely.

Yet the use of AI and algorithms for medical purposes varies enormously in the international arena. ${ }^{17}$ Digitalization's international differences accentuated - in China online COVID whistleblowers disappeared. ${ }^{18}$ Strategically-internet-controlling Asia ${ }^{19}$ and the former Soviet world trumped on mobile crowd control ${ }^{20}$ and social monitoring compliance (Ackerman, 2020). ${ }^{21}$ US S\&P 500 leaders $^{22}$ partnered $^{23}$ to pool health data ${ }^{24}$ while freedom-of-speech-fueled-informationoverload could deadlock relevant communication. ${ }^{25}$ Europe emphasized privacy protection ${ }^{26}$ in envisioning ${ }^{27}$ a $5^{\text {th }}$ freedom of data ${ }^{28}$ to harvest network effects of exponentially-growing marginal utility of information.

The prospective post-COVID $\mathrm{era}^{29}$ will likely show advanced healthcare. Elder and chronic patients' passing opens market opportunities and fiscal space to evolutionary-dominant, young Corona-survivors. Future global digital healthcare innovations are more likely and favorable to come from corruption-free AI pioneering countries that tend to have better general medical care. Internet connectivity and AI-human-compatibility via tech-skills and digital affinity are growing competitive advantages (Puaschunder, 2019d, e). The following empirical part therefore provides information on country-specific differences in AI leadership on global public health. Countries that feature AI-growth potential with non-corrupt institutional support and good general healthcare systems are presented to be in a better position to lead the world on global pandemic monitoring and crisis management.

\section{Empirical validation}

The empirical part presents three indices that highlight the influence of the three different components of AI, corruption and healthcare for future public health solution finding: (1) An index based on internet connectivity - as a proxy for digitalization and AI advancement- as well as Gross Domestic Product (GDP) - as indicator for economic productivity - is first calculated to outline global AI innovation hubs with economic impetus around the world. (2) A novel anti-corruption artificial healthcare index is then presented that highlights countries in the world that have vital AI growth in a non-corrupt environment. (3) Finally, an index is created that integrates internet connectivity, anti-corruption as well as healthcare access and quality. ${ }^{30}$ 
(1) AI-GDP Index: AI entrance into economic markets was modeled into the standard neoclassical growth theory by creating a novel index for representing growth in the artificial age. The AI_GDP per country $c$ index was calculated for 191 countries of the world based on Equation 1, comprised of the GDP per capita per country $c$ and AI internet connectivity percentage of a country, $\operatorname{IA}(c)$.

$$
A I_{-} G D P(c)=G D P_{c} * I A_{c}
$$

(Equation 1)

GDP per capita was retrieved from a World Bank database for the year $2017^{31}$ multiplied by AI entrance measured by the proxy of Internet Access percent per country, $I A(c)$, which represents country $c$ inhabitants' internet usage in percent of the population as retrieved from a World Bank database for $2017^{32}$ (Puaschunder, 2020). The table section in Graph 1-A in the appendix holds the AI_GDP (c) index value per country and tables the $A I_{-} G D P$ countries' indices ranked from the highest to the lowest. Graph 1 displays the $A I_{-} G D P$ country's index around the world. The higher the index, the more connected and the higher the GDP is and the darker the country is colored in Graph 1.

Graph 1: AI-GDP Index for 191 countries of the world

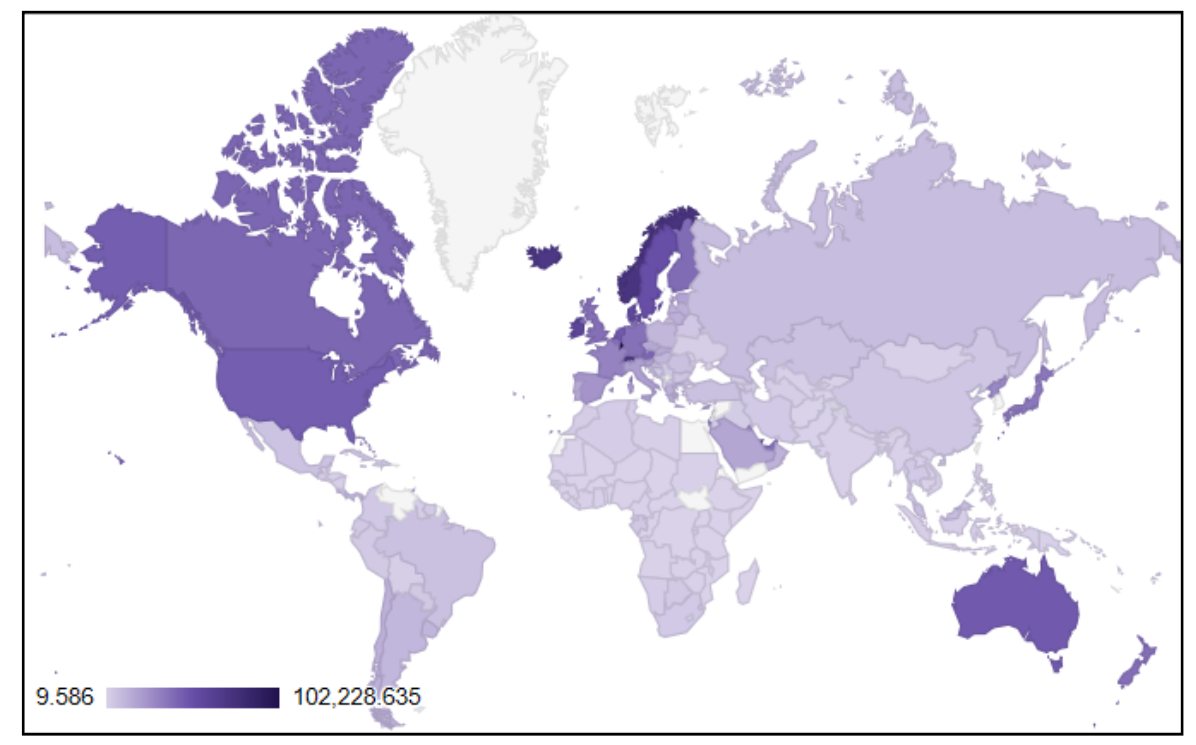

As visible in Graphs 1, continent-specific AI-GDP relations reveal Africa being relatively low on AIGDP. Asia and the Gulf region are in the middle ranges with Qatar and United Arab Emirates and Japan and South Korea leading. In Europe Luxembourg, Switzerland, Norway, Iceland, Ireland, Sweden and Finland are top AI-GDP countries. North America has a higher AI-GDP index than South America, where Chile, Argentina and Uruguay appear to lead. In Oceania Australia has a higher AIGDP index than New Zealand. The parts of the world that feature internet connectivity and high GDP are likely to pioneer on AI-driven big data monitoring insights for pandemic prevention. AI advancements should be put into relation with anti-corruption, as integer institutions will aid a successful implementation of AI and healthcare (Campos \& Pradhan, 2007; Escresa \& Picci, 2017; Mungiu-Pippidi \& Dadašov, 2016; Rose-Ackerman \& Palifka, 2016; Rose-Ackerman \& Tan, 2014). ${ }^{33}$

(2) Corruption Perception (CPI)-Global Connectivity (GCI) Index: In a cross-sectional study of 79 countries' relation of Corruption Perception - measured by the Corruption Perception Index of $2019^{34}$ - and global connectivity (GCI) - as captured by the Global Connectivity Index for $2019,{ }^{35} \mathrm{AI}$ is significantly positively correlated with anti-corruption $\left(r_{\text {Pearson }}=.860, n=79, p<\right.$ .000). AI comes from parts of the world that are perceived as less corrupt. An AI_anti-corruption index $A A$ is calculated based on Equation 2, comprised of the global connectivity (GCI) of a country $c$ in 2019 multiplied by the Corruption Perception Index of the same country $c$ in 2019. 
The table section in Graph 2-A in the appendix holds the AI_anticorruption $(A A)$ index value per country and tables the $A I_{-}$anticorruption $(A A)$ countries' indices ranked from the highest to the lowest. Graph 2 displays the AI_anticorruption $(A A)$ country's index around the world. The higher the index, the better connected and less corrupt the country is perceived, and the greener the country is colored. The lower the index, the less connected and the more corrupt the country is perceived, and the redder the country is colored. Medium connectivity and corruption perception are colored in yellow.

Graph 2: AI-anticorruption (AA) index for 79 countries of the world

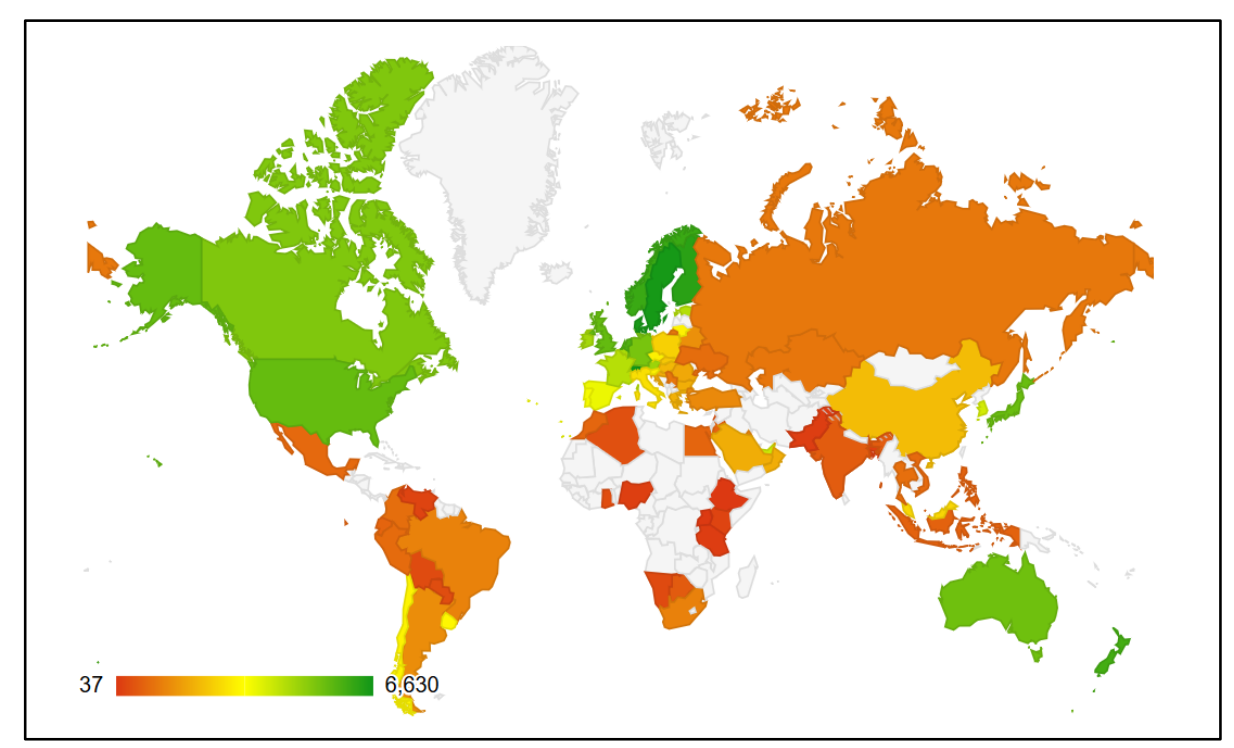

Artificial Intelligence (AI) - measured by Global Connectivity - is significantly positively correlated with freedom from corruption. AI thus springs from non-corrupt territories of the world. AI therefore offers a relatively corruption-free leadership decision making tool, which could improve support of healthcare in non-corrupt global pandemic solutions. Artificial global governance should therefore come from the countries with high global connectivity and low corruption that are exhibited in the lower right quadrant in Graph 3.

Graph 3: Global connectivity (GCI) and Corruption Perception Index (CPI)

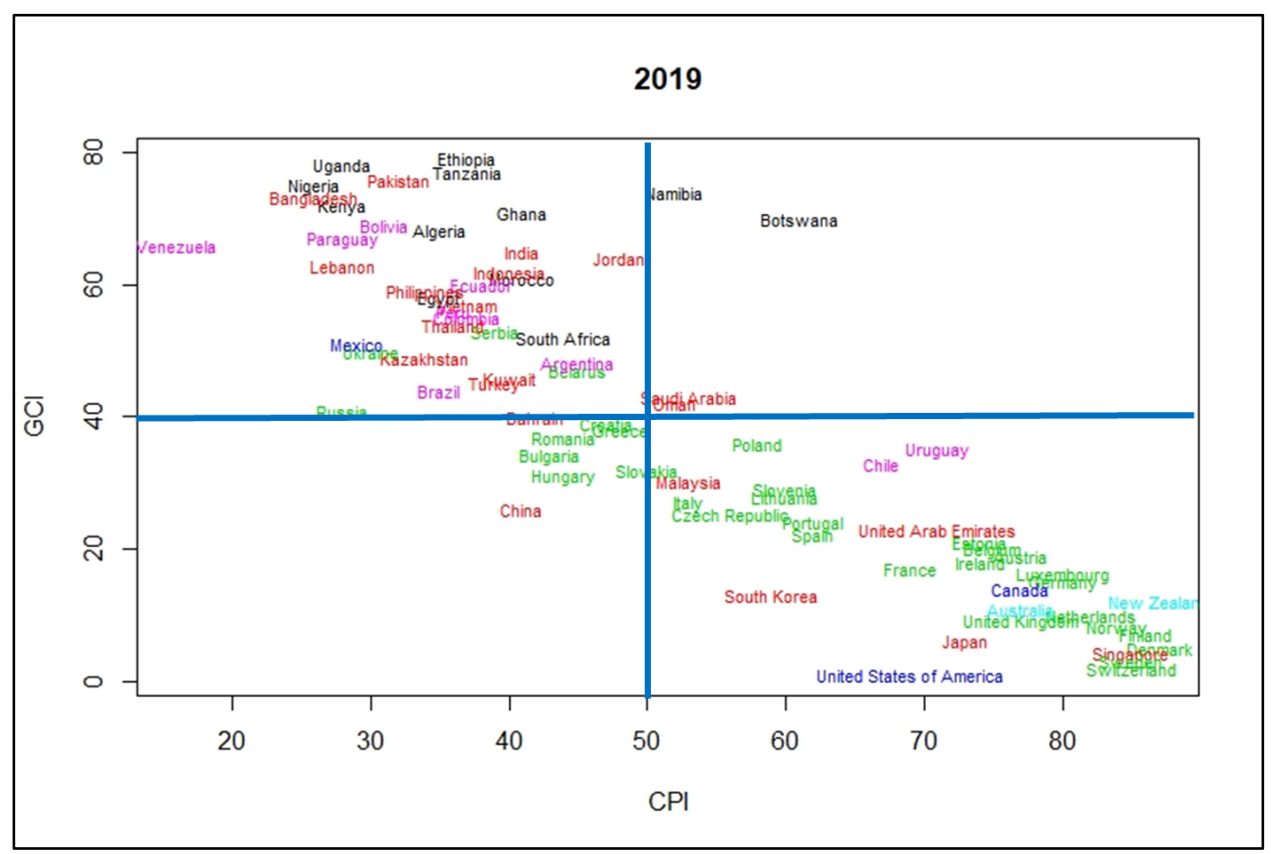


Those countries that rank high on AI and corruption freedom could lead on building AI to monitor international public health and solve global healthcare problems. Artificial global governance in noncorrupt territories could unprecedentedly aid on global healthcare for protection and security of humankind. The detected non-corrupt AI centres exhibited in the right downward quadrant hold comparative advantages to lead on global artificial healthcare solutions against COVID-19 and serve as pandemic crisis and risk management innovators of the future.

Continent-specific relations reveal Africa being relatively low on AI and problematic on corruption as visible in Graph 3. Asia and the Gulf region are more in the middle ranges but still feature unfavorable levels of corruption. Singapore, Japan, South Korea and United Arab Emirates but also Malaysia seem to be leading on AI and less corruption in Asia and the Middle East. In Europe Switzerland, Nordic countries like Sweden, Denmark, Norway and Finland are top AI and anti-corruption countries. North and South America are opposites - while the United States of America has a top condition to lead on AI and anti-corruption; South America and especially Venezuela, Paraguay and Bolivia, rank lowest on AI and relatively worse on corruption. In Oceania New Zealand has a better AI and anti-corruption index performance than Australia.

(3) Corruption Perception (CPI)-Global Connectivity (GCI)-Healthcare Index: In a crosssectional study of 79 countries' relation of Corruption Perception - measured by the Corruption Perception Index of $2019^{36}$ - and global connectivity (GCI) - as captured by the Global Connectivity Index for $2019^{37}$ - and healthcare - as quantified by the 2016 Healthcare Quality and Access Index ${ }^{38}$ - freedom from corruption is significantly positively correlated with good healthcare $\left(r_{\text {Pearson }}=.715, n=79, p<.001\right)$ and AI is significantly positively correlated with good healthcare $\left(r_{\text {Pearson }}=.896, n=79, p<.001\right)$. AI comes from parts of the world that are perceived as less corrupt and feature better public healthcare.

An AI_anticorruption_health index $A A H$ is calculated based on Equation 3, comprised of the global connectivity (GCI) of a country $c$ in 2019 multiplied by the Corruption Perception Index of country $c$ in 2019 and multiplied by the Health Quality and Access Index of 2016. ${ }^{39}$

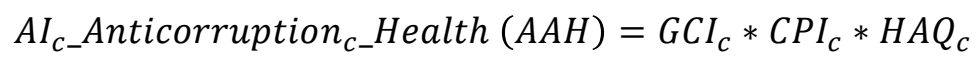

(Equation 3)

The table section in Graph 3-A in the appendix holds the AI_anticorruption_health $(A A H)$ index value per country and tables the $A I_{-}$anticorruption_health $(A A H)$ countries' indices ranked from the highest to the lowest. Graph 4 displays the AI_anticorruption_health $(A A H)$ country's index around the world. Graph 4 highlights the parts of the world that feature high internet connectivity, freedom from corruption and good access to and quality of general healthcare in green, whereas those parts of the world that feature less internet connectivity and more perceived corruption and worse access to and quality of general healthcare in red. The higher the index, the better connected and less corrupt the country is perceived and the better access to and quality of general healthcare is offered in the greener-colored countries. The lower the index, the less connected and the more corrupt the country is perceived and the worse off are its citizens regarding access to and quality of general healthcare, and the redder the country is colored. Medium AIconnectivity and corruption hubs with medium access to and quality of healthcare are displayed in yellow. 
Graph 4: AI-anticorruption-health (AAH) index for 79 countries of the world

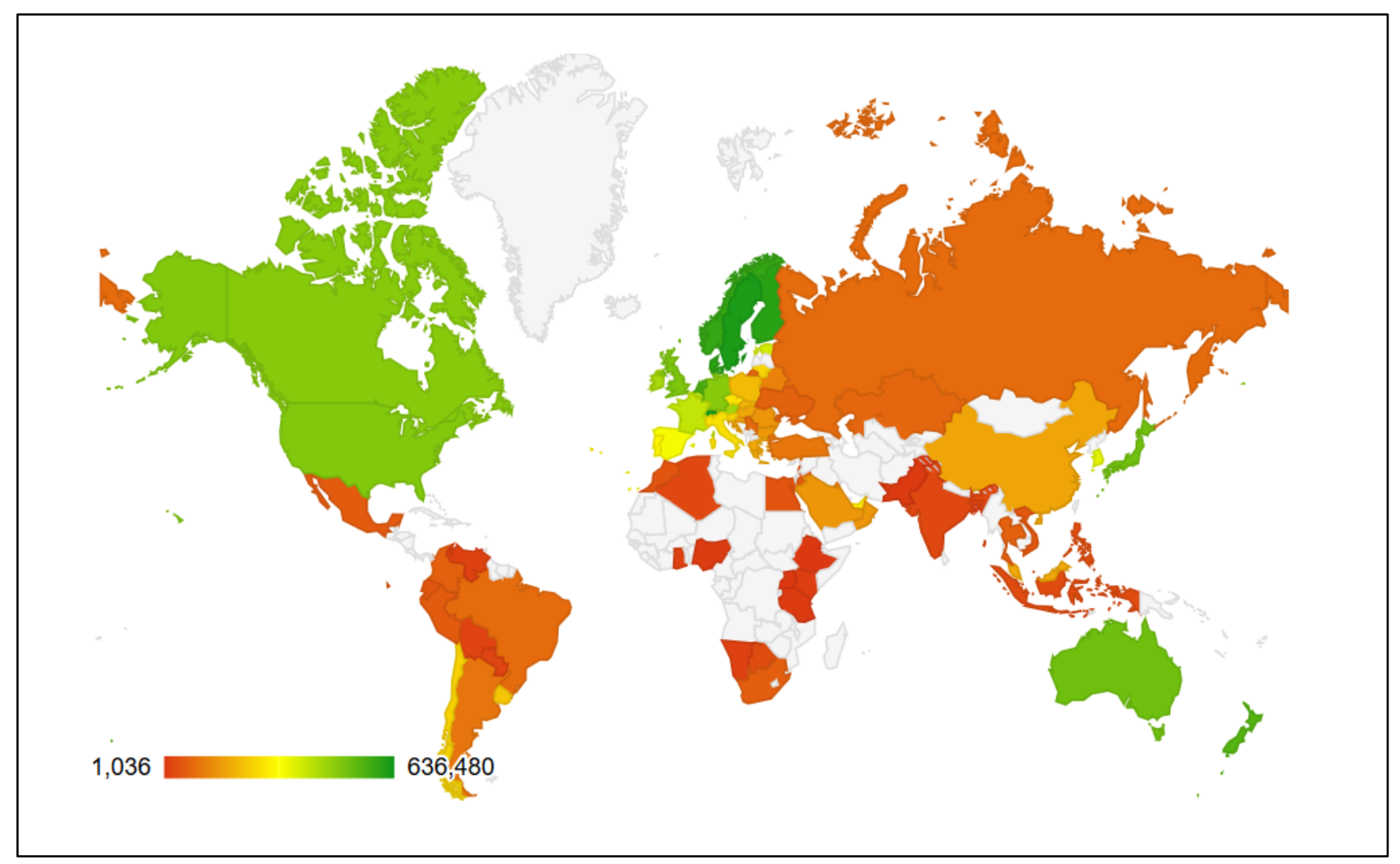

Continent-specific relations reveal Africa being relatively low on AI, problematic on corruption as well as general healthcare as visible in Graph 4. Asia and the Gulf region are more in the middle ranges but still feature problematic levels of corruption and relatively weak access and quality of healthcare. Singapore, Japan, South Korea and United Arab Emirates but also Malaysia seem to be leading on AI, anti-corruption as well as access to and quality of healthcare in Asia and the Middle East. European countries like Switzerland and the Nordic countries - such as Sweden, Finland, Denmark and Norway are top AI and anti-corruption territories with excellent general healthcare. North and South America are opposites again - while the United States of America has a top condition to lead on AI anti-corrupt and with excellent healthcare; South America, and there especially Venezuela, Bolivia and Paraguay, rank lowest on AI and relatively worse on corruption and general healthcare. In Oceania the leading New Zealand and immediately-thereafter ranked Australia have almost the same conditions on the AI, anticorruption and healthcare index.

\section{Discussion}

The currently ongoing COVID-19 crisis has created an unprecedented need for the global community to collaborate on public healthcare solutions in the international compound. International healthcare pandemic crisis and risk management could thereby be most innovatively fostered by AI and big dataderived inferences to control the currently ongoing COVID-19 pandemic. At the same time, international differences in the approaches to combat global pandemics with the use of algorithms became currently more apparent than ever before.

The article provided three indices that depict the international differences in digitalization, economic potential, anti-corruption and access to general healthcare. In a multi-faceted analysis, different aspects and combinations of AI-led growth, anti-corruption and health were highlighted. The results were meant as quantified decision making aid on the comparative advantages to lead the world in global, digitalized pandemic prevention and risk management. The countries that score 
high on AI, GDP, anti-corruption and healthcare excellence were featured as ultimate worldleading, innovative global pandemic alleviation centres.

While information was presented on how the different countries rank compared to each other on their potential of using AI to avert global pandemics, we still need a further qualitative understanding of the ethical boundaries of digitalization in healthcare.

A worldwide solution on AI helping against global virus spreads will require equal access to information of health data. The sharing of data will need several countries coming together to construct large datasets as learning opportunities, which different stakeholders from government, healthcare, engineering and technology can use to analyze and predict the prevailing health situation and outcomes. The more countries join, the more accurately the dataset will be able to draw inferences about world-wide prevalent epidemics spread and global diseases. An environment should be established in which research, clinical practice and technological advancement are coming together for retrieving data insights. Big data should combine the medical sector with technology-driven self-monitoring directly applied to patients in a near real-time manner. Large data sets that glean context-based information could thereby become early warning signs of imminent viral epidemic outbreaks (Puaschunder \& Gelter 2019).

Within the European compound, a $5^{\text {th }}$ freedom of data should incentivize data sharing and provide the legal means for combating discrimination based on big data-derived inferences as well as protection of privacy (Puaschunder \& Gelter, 2019). The wisdom of the crowds could also be tapped into in citizen science - e.g., Massively Multiplayer Online Gaming (MMOG) techniques that have been used to incentivize volunteer participation. Such an approach helped gamers on a crowdsourced gaming science site ${ }^{40}$ to decode an AIDS protein in 3 weeks, a problem that had stumped researchers for 15 years (Quadir, Rasool, Zwitter, Sathiaseelan \& Crowcroft 2016).

AI regulations from governments and their agencies account for the most cutting-edge sophistication of laws and public policies yet hold also enormous unknown risks. The most contested areas of legal and policy attention include data protection and privacy, transparency, human oversight and surveillance. Privacy challenges arise from big data building and hands-on search for a desired pandemic spreading monitoring system. Instant and continuous information tracking implying full transparency leads to the risk of stigmatization as diagnosis influences future diagnoses sets patients up on a path of discriminatory disadvantages or silos of sickness imbuing extensive health risks.

A combination of mobile technology and cloud computing naturally complements big data technologies and is well-suited for reliable storage and analysis of big data. Crowdsourcing comes in when a mapping type of search option would exist that displays all medical services in a map. In such a crowdsourced mapping, all medical services nearby could be displayed featuring a price scale and performance information based on consumer reviews. Advantages of individuals sharing information about price and quality of medical services would be the quality control, transparency and prospected price margin decrease. Information democratization as the equal access to information thus appears to be favourable coupled with targeted information provision that does not reveal private information or pits people against each other. Yet downsides of an as such type of mapping comprise of social stigmatization and discrimination potential, competitive fraud, price decline leading to a natural service quality race-to-the-bottom. This occurs when information is used for deriving inferences that can be used against the individual, especially vulnerable groups and impaired, for instance in hiring or access to education decisions. In order to avoid a predicament between utility of information aggregation versus dignity in privacy, a single representation of tailored information but not an aggregated information display that pits people against each other or ranks them based on their health status is recommended. Additional IT solutions are to avoid tracking of individuals but their use of the environment - for instance via Bluetooth tracking of medical devices such as pharmaceuticals.

In the future of artificial healthcare, compatibility problems in the adoption of new technologies around the world should be alleviated by research and training in international literacy in the use of digitalization. Transnational engagement could aid in re-evaluating and seeking out 
new competencies, technology solutions and data sources that better support patient-centric outcomes. Patients must be trained to use digital channels and be open to remote assistance.

This massive market entrance of AI in our contemporary economy also imposes historically unique challenges (Puaschunder, 2019c). Ethical challenges that may also open gates for corrupt activities include digital security threats related to AI. "Data poisoning" - feeding manipulated data into a grid on which an AI system is being trained - or unqualified e-workers' ratings can cause misclassifications. Such adversarial examples can be created without effort, by printing images on normal paper and photographing it with a smartphone (OECD, 2019).

In addition, the emerging autonomy of AI holds unique potentials of eternal life of robots, AI and algorithms alongside unprecedented economic superiority, data storage and computational advantages. Yet to this day, it remains unclear what impact AI taking over the workforce will have on economic growth (Puaschunder, 2019b, d; Puaschunder, 2020). Artificial diplomacy could learn from ancient legal codes that had a diversified citizenry, such as the ancient Athenian city state democracy featuring diversified citizenship rights. Ancient legal codes may also help craft the ethical boundaries or find innovative natural law derived tools how to alleviate corruption in the digital age and flourish global health.

\section{References}

Ackermann, Klaus. 2020. Limiting the market for information as a tool of governance: Evidence from Russia. Melbourne, Australia: Monash University working paper.

Agerberg, Mattias. 2019. "The Lesser Evil? Corruption Voting and the Importance of Clean Alternatives." Comparative Political Studies 52: 1-3.

Ahmed, Hosny, Chintan Parmar, John Quackenbush, Lawrence H. Schwartz \& Hugo Aerts. 2018. "Artificial intelligence in radiology." National Reviews Cancer 18(8): 500-510.

Alt, James E. and David Dreyer Lassen. 2012. "Enforcement and Public Corruption: Evidence from the American States." Journal of Law, Economics, and Organization 30(2): 306-38.

Bardhan, Pranab. 2016. "State and Development: The Need for a Reappraisal of the Current Literature." Journal of Economic Literature 54(3):862-892.

Boucher, Alix J., et al. 2007. Mapping and Fighting Corruption in War-Torn States, Stimson Center Report No. 61, Washington DC: Henry L. Stimson Center, March 2007.

Campos, J. Edgardo and Sanjay Pradhan. 2007. The Many Faces of Corruption, World Bank.

Charron, Nicholas, Mihaly Fazekas, and Victor Lapuente. 2016. "Careers, Connections, and Corruption Risks: Investigating the Impact of Bureaucratic Meritocracy on Public Procurement Processes." Journal of Politics 79(1):89-104.

Cooley, Alexander and J.C. Sharman. 2015. "Blurring the Line between Licit and Illicit: Transnational Corruption Networks in Central Asia and Beyond." Central Asian Survey 34: 11-28.

Davis, Kevin and Michael J. Trebilcock. 2008. "The Relationship between Law and Development: Optimists versus Skeptics." American Journal of Comparative Law 56:895-946.

Davis, Kevin E.. 2019. Between Impunity and Imperialism: The Regulation of Transnational Bribery. New York: Oxford University Press.

Dowell, Ryan. 2018. "Fundamental protections for non-biological intelligences or: How we learn to stop worrying and love our robot Brethren." Minnesota Journal of Law, Science \& Technology 19 (1): 305-336.

Engel, Eduardo, Delia Ferreira Rubio, Daniel Kaufmann, Armando Lara Yaffar, Josa Londoño Saldarriaga, Beth S. Noveck, Mark Pieth, Susan Rose-Ackerman. 2018. Report of the Expert Advisory Group on Anti-Corruption, Transparency, and Integrity in Latin America and the Caribbean, Inter-American Development Bank, November 2018. Retrieved at https://publications.iadb.org/bitstream/handle/11319/9305/Report-of-the-ExpertAdvisory-Group-on-Anti-Corruption-Transparency-and-Integrity-in-Latin-American-and-the-

Caribbean.pdf? sequence $=1 \&$ is Allowed $=\mathrm{y}$.

Escresa, Laarni and Lucio. Picci. 2017. "A New Cross-National Measure of Corruption." The World Bank Economic Review 31 (1): 196-218.

Fisman, Raymond and Edward Miguel. 2007. "Corruption, Norms, and Legal Enforcement: Evidence from Diplomatic Parking Tickets," 115(6) Journal of Political Economy, 1020-1048,

Gordon, Sanford C. 2009. "Assessing Partisan Bias in Federal Public Corruption Prosecutions." American Political Science Review 103(4): 534-554.

Gowling WLG. 2019. Emerging legal issues in an AI-driven world. Lexology.com. Available at https://www.lexology.com/library/detail.aspx?g=4284727f-3bec-43e5-b230-fad2742dd4fb. 
Groebel, Robert. 2019. Excellence in the era of precision medicine. 06/11/2019. Pharma IQ. https://www.pharmaiq.com/business-development/articles/excellence-in-the-era-of-precision-medicine.

Hite-Rubin, Nancy. 2015. "A Corruption, Military Procurement and FDI Nexus." In Susan Rose-Ackerman and Paul Lagunes, eds. Greed, Corruption and the Modern State (Cheltenham UK: Edward Elgar, 2015) pp. $224-251$.

Holmes, Leslie. 2007. “The Corruption-Organised Crime Nexus in Central and Eastern Europe.” In Leslie Holmes, ed. Terrorism, Oranised Crime and Corruption; Networks and Linages (Cheltenham UK: Edward Elgar, 2007) pp. 84-108.

Johannesen, Niels \& Gabriel Zucman. 2014. "The end of bank secrecy? An evaluation of the G20 tax haven crackdown." American Economic Journal: Economic Policy 6(1): 65-91.

Klumpp, Tilman, Hugo M. Mialon, \& Michael A. Williams. 2016. "The Business of American Democracy: Citizens United, Independent Spending, and Elections. The Journal of Law and Economics 59(1): 1-43.

Knapton, Sarah. 2016. "Microsoft will 'solve' cancer within 10 years by 'reprogramming' diseased cells." The Telegraph, September 20, 2016. Retrieved at https://www.telegraph.co.uk/science/2016/09/20/microsoft-willsolve-cancer-within-10-years-by-reprogramming-dis/.

Lagasse, Jeff. 2018. Healthcare AI market expected to surge from \$2.1 to \$36.1 billion by 2025. Healthcare Finance. https://www.healthcarefinancenews.com/news/healthcare-ai-market-expected-surge-21-361-billion-2025.

Le Billon, Philippe. 2003. "Buying Peace or Fueling War: the Role of Corruption in Armed Conflicts." Journal of International Development 15: 413-426.

McLean, Nicholas M.. 1970-2011, 2012. "Cross-National Patterns in FCPA Enforcement.” 121 Yale L.J.

MedicalFuturist. 2020. Digital Health Apps to Use During the COVID-19 Quarantine. https://medicalfuturist.com/digital-health-apps-to-use-during-the-covid-19-quarantine/.

Mungiu-Pippidi, Alina and Ramin Dadašov. 2016. "Measuring control of corruption by a new index of public integrity." European Journal on Criminal Policy and Research 22:415-438.

Noyes, Katherine. 2016. "5 things you need to know about A.I.: Cognitive, neural and deep, oh my!" Computerworld, March 3, 2016. Retrieved at www.computerworld.com/article/3040563/enterprise applications/5-things-youneed-toknow-aboutai-cognitive-neural-anddeep-oh-my.html.

OECD 2015. Data-driven innovation: Big data for growth and well-being. Paris: OECD. Retrieved at http://dx.doi.org/10.1787/9789264229358-en

OECD 2019. Artificial intelligence in society. Paris: OECD.

Pakdemirli, Emre. 2019. "Artificial intelligence in radiology: Friend or foe? Where are we now and where are we heading?" Acta Radiologica Open 8(2): 1-5, 2019.

Puaschunder, Julia Margarete \& Martin Gelter. 2019. "On the political economy of the European Union.” Proceedings of the 15th International RAIS Conference on Social Sciences and Humanities at Johns Hopkins University, MD, United States, November 6-7, 2019, pp. 1-9. Retrieved at http://rais.education/wpcontent/uploads/2019/11/001JP.pdf.

Puaschunder, Julia Margarete. 2019a. “Artificial Intelligence, big data, and algorithms in healthcare.” Report on behalf of the European Parliament European Liberal Forum in cooperation with The New Austria and Liberal Forum, 2019a. Retrieved at https://papers.ssrn.com/sol3/papers.cfm?abstract_id=3472885.

Puaschunder, Julia Margarete. 2019b. “Artificial Intelligence market disruption.” Proceedings of the International RAIS Conference on Social Sciences and Humanities at Johns Hopkins University, MD, United States, June 10-11, pp. 1-8.

Puaschunder, Julia Margarete. 2019c. “On Artificial Intelligence’s razor's edge: On the future of democracy and society in the artificial age." Journal of Economics and Business 2(1): 100-119.

Puaschunder, Julia Margarete. 2019d. Stakeholder perspectives on Artificial Intelligence (AI), robotics and big data in healthcare: An empirical study, Retrieved at https://papers.ssrn.com/sol3/papers.cfm?abstract_id=3497261.

Puaschunder, Julia Margarete. 2019e. The legal and international situation of AI, robotics and big data with attention to healthcare. Reports on behalf of the European Parliament European Liberal Forum in cooperation with The New Austria and Liberal Forum, Retrieved at https://papers.ssrn.com/sol3/papers.cfm?abstract_id=3472885

Puaschunder, Julia Margarete. 2020. "Revising growth theory in the Artificial Age: Putty and clay labor." Archives in Business Research 8(3): 65-107.

Quadir, Junaid, Anwaar Ali, Raihan ur Rasool, Andrj Zwitter, Arjuna Sathiaseelan \& Jon Crowcroft. 2016. "Crisis analytics: Big data-driven crisis response.” Journal of International Humanitarian Action 1(1): 12-21

ReportLinker. 2018. Artificial Intelligence in Healthcare Market by Offering, Technology, End-Use Application, End User And Geography - Global Forecast to 2025. https://www.reportlinker.com/p04897122/Artificial-Intelligence-inHealthcare-Market-by-Offering-Technology-Application-End-User-Industry-and-Geography-Global-Forecastto.html.

Rose-Ackerman, Susan and Bonnie J. Palifka. 2016. Corruption and Government: Causes, Consequences, and Reform, Cambridge UK: Cambridge University Press.

Rose-Ackerman, Susan and Paul D. Carrington 2013. eds. Anti-Corruption Policy: Can International Actors Play a Constructive Role? Durham NC: CAP Press.

Rose-Ackerman, Susan and Paul Lagunes. 2015. eds. Greed, Corruption and the Modern State. Cheltenham UK: Edward Elgar. 
Rose-Ackerman, Susan and Yingqi Tan. 2014. "Corruption in the Procurement of Pharmaceuticals and Medical Equipment in China: The Incentives Facing Multinationals, Domestic Firms, and Hospital Officials." UCLA Pacific Basin Law Journal 32(1): 1-54.

UNDP. 2019. Human Development Report 2019. Beyond income, beyond averages, beyond today: Inequalities in human development in the 21st century. New York. http://hdr.undp.org/sites/default/files/hdr2019.pdf.

Vlasic, Mark V. \& Peter Atlee. 2012. "Democratizing the Global Fight Against Corruption; the Impact of the DoddFrank Whistleblower Bounty on the FCPA, Fletcher Forum on World Affairs 36: 79-92 (2012), pp. 83-88.

Wright, Elizabeth. 2020. Trump Administration's Initiatives to Cut Government Red Tape to Attack the COVID-19 Virus, March 23, 2020, $C A G W$. https://www.cagw.org/thewastewatcher/trump-administrations-initiatives-cutgovernment-red-tape-attack-covid-19-virus. 


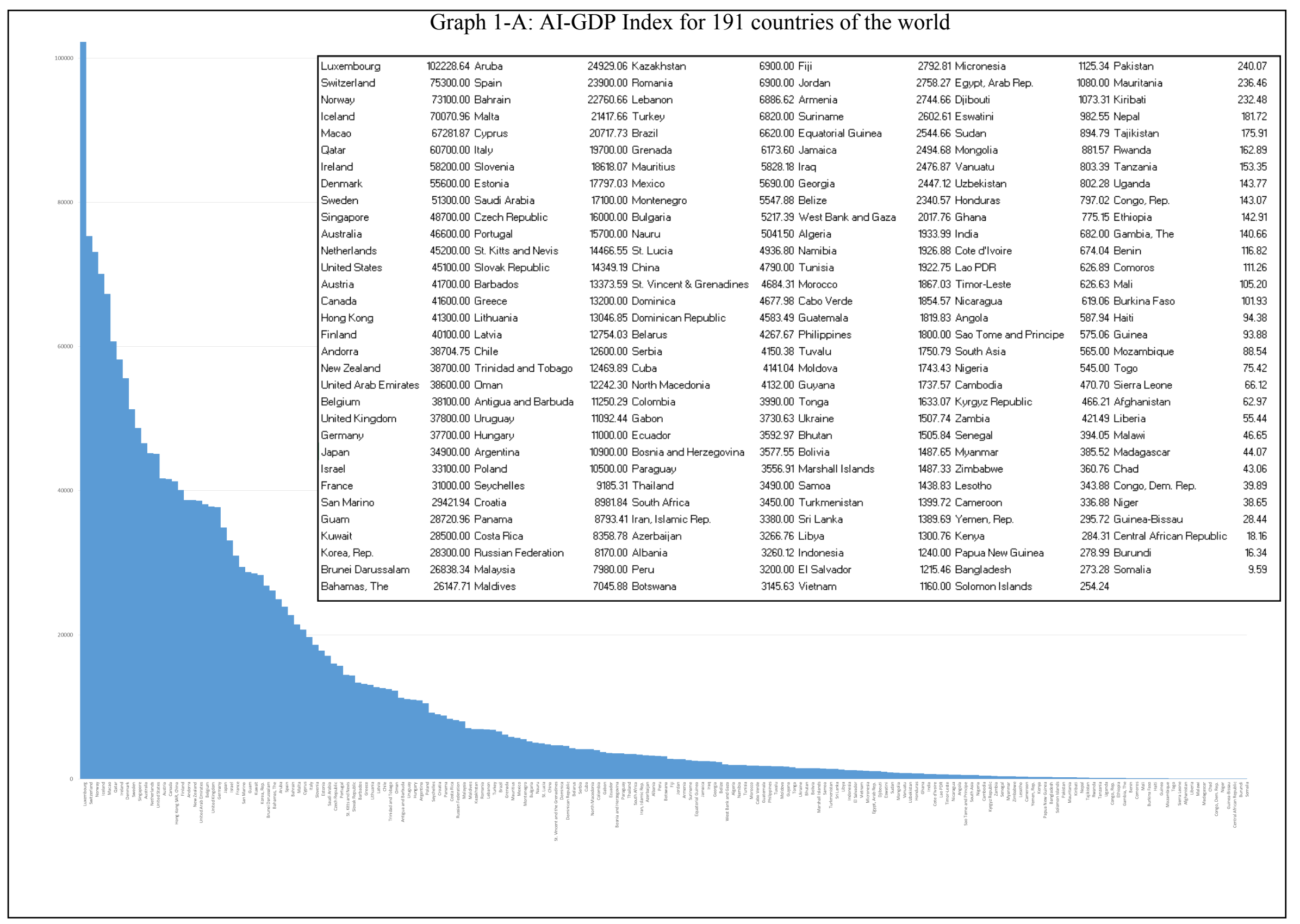




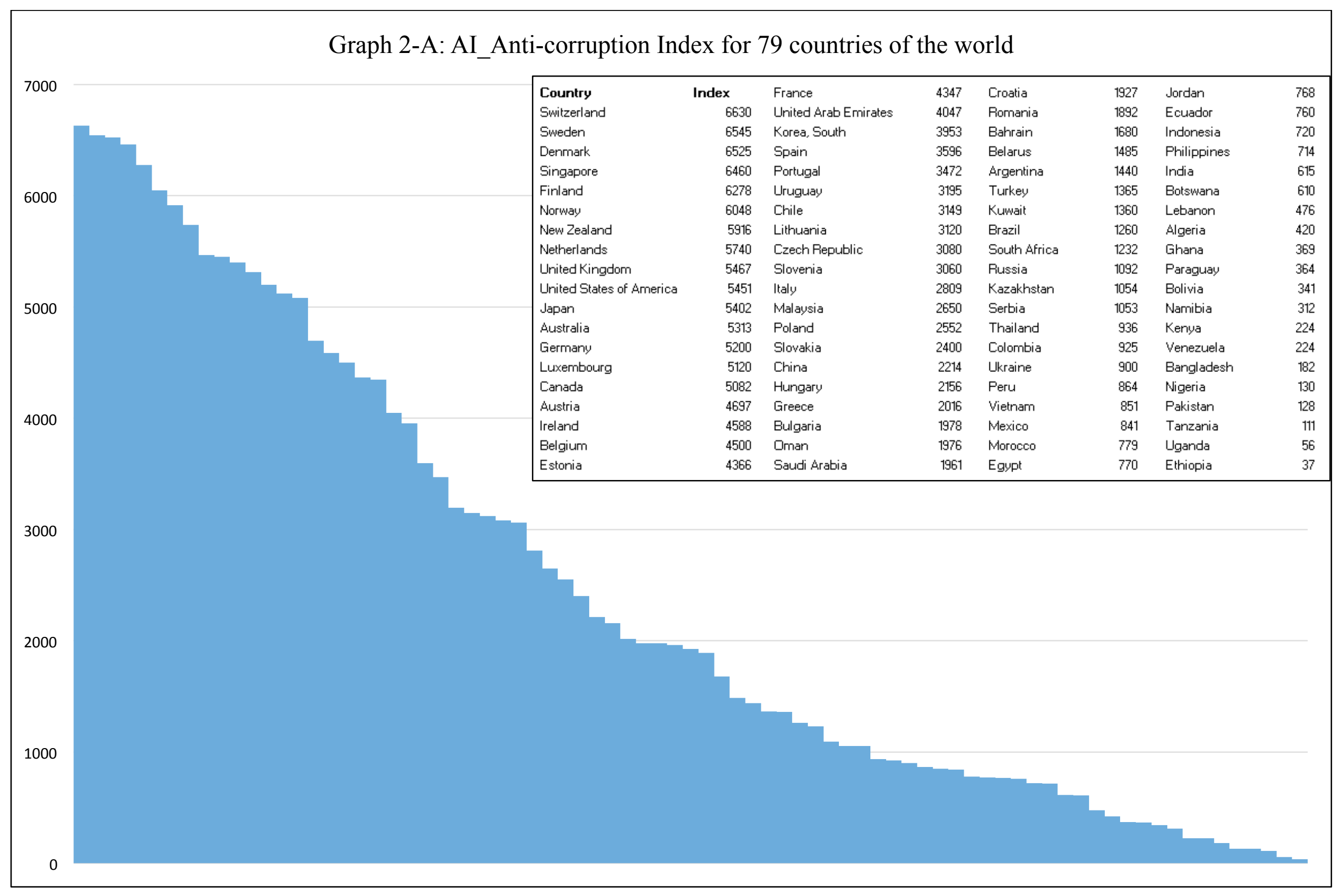




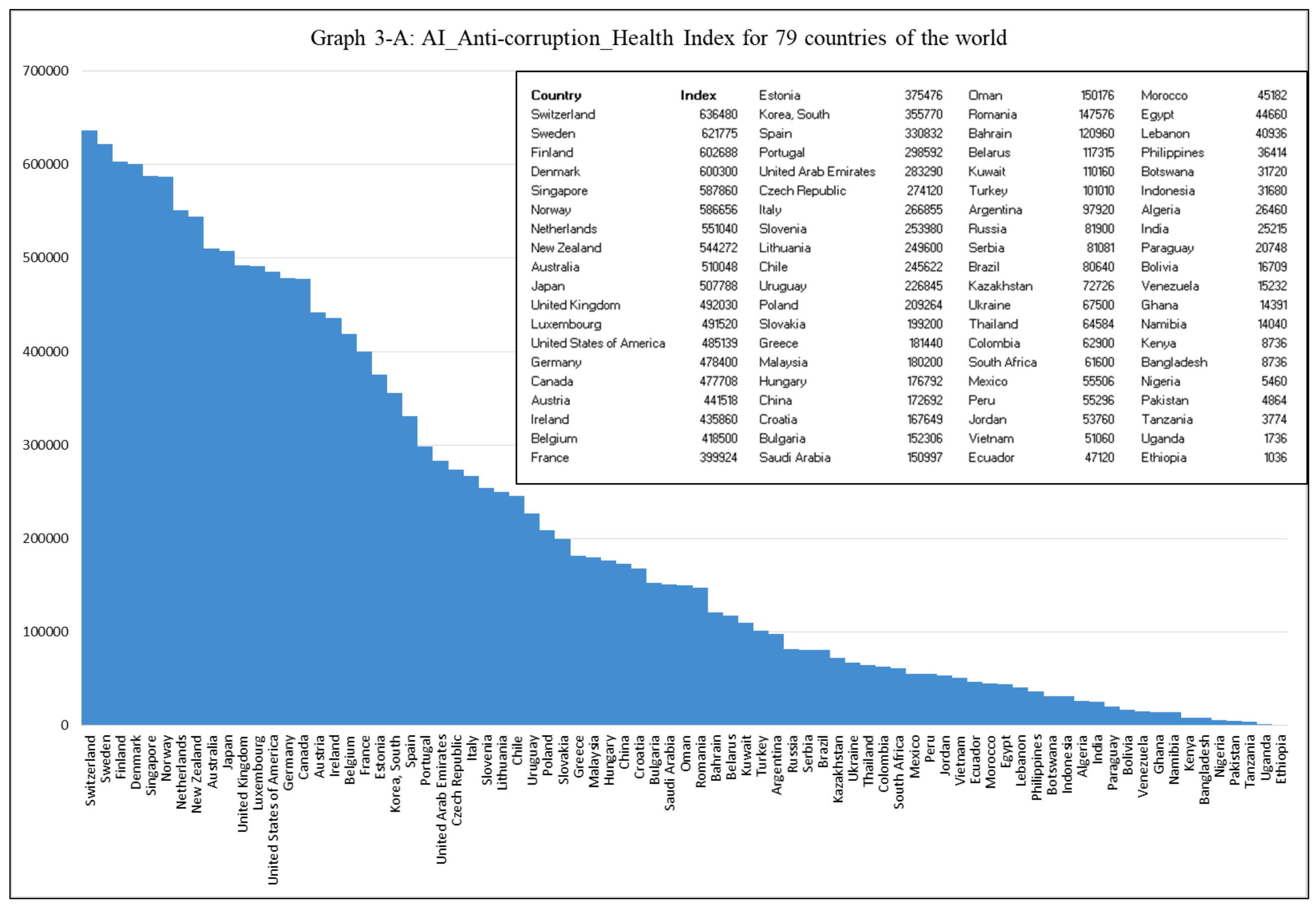




\footnotetext{
${ }^{1} \mathrm{https}: / / \mathrm{www}$. thelancet.com/journals/lancet/article/PIIS0140-6736(18)30994-2/fulltext

${ }^{2}$ http://www.ti-defence.org/

https://www.law.cornell.edu/uscode/text/15/78dd-1\#

http://www.legislation.gov.uk/ukpga/2010/23/contents
}

https://www.globalwitness.org/en/blog/2016-draws-close-new-laws-fight-corruption-us-and-uk-kick/ http://www.fcpablog.com/blog/2016/12/19/congress-adopts-global-magnitsky-human-rights-act.html http://www.oecd.org/corruption/oecdantibriberyconvention.htm

http://www.unodc.org/pdf/crime/convention_corruption/signing/Convention-e.pdf

$\mathrm{http}: / / \mathrm{www}$.freeenterprise.com/search/content/fcpa

${ }^{3} \mathrm{http}: / / \mathrm{www}$. corruptionprevention.net/

${ }^{4} \mathrm{http}: / /$ www.corpwatch.org/

${ }^{5} \mathrm{http}: / / \mathrm{www}$. consumer-action.org/

${ }^{6} \mathrm{https}: / / \mathrm{www}$.accountability.org/

${ }^{7} \mathrm{https}: / /$ www.preventionweb.net/organizations/2545

${ }^{8} \mathrm{http}: / /$ www.developmentgateway.org/

${ }^{9} \mathrm{https}$ ://integrityaction.org/

${ }^{10} \mathrm{http}: / / \mathrm{www}$. worldbank.org/en/topic/governance/brief/anti-corruption

https://www.imf.org/external/pubs/ft/ar/2018/eng/spotlight/reducing-corruption/

https://www.transparency.org/research/gcr/

http://www.globalintegrity.org/

https://www.globalwitness.org/en/

http://www.oecd.org/g20/topics/anti-corruption/

http://anticorrp.eu/project/overview/

http://www.dfid.gov.uk/

${ }^{11} \mathrm{https}$ ://www2.monash.edu/impact/articles/big-data/how-novel-coronavirus-covid-19-is-putting-a-strain-on-global-internetnetworks/

${ }^{12}$ TUtheTop COVID-19 Expertenrunde \#2: Wirtschaft in the Krise, March 27, 2020 online at

https://zoom.us/webinar/register/WN_V1x7X2V4TI6hjn4zNVxGMA?fbclid=IwAR2JyEtpkUoz0aL9X2sEwhevt8F8JBQjDk3_rTJb

eGkE0aRWYNnl72AV4U4\&ct=t(TTTac_COVID-19_ECONOMY)\&mc_cid=2df1caa7d2\&mc_eid=56675af841

${ }^{13} \mathrm{https} / / / \mathrm{www} . \mathrm{cnn} . \mathrm{com} / 2020 / 04 / 04 / \mathrm{us} /$ nyc-schools-zoom-online-security/index.html

${ }^{14} \mathrm{https}: / /$ www.pepp-pt.org/content

${ }^{15} \mathrm{http}: / /$ news.mit.edu/2020/bluetooth-covid-19-contact-tracing-0409

${ }^{16}$ The 17th Annual Health Care Conference at Harvard. February 9, 2020 at Harvard Business School retrieved at https://www.hbshealthconference.com/

${ }^{17} \mathrm{https}$ //www.msn.com/de-de/nachrichten/coronavirus/who-konferenz-startet-mit-milliardenspende-aus-china/ar-

BB14fm6r?ocid=spartanntp

${ }^{18} \mathrm{https}: / / \mathrm{www}$. businessinsider.com/china-coronavirus-whistleblowers-speak-out-vanish-2020-2

${ }^{19} \mathrm{https}: / /$ www.bbc.com/news/world-asia-india-50819905

${ }^{20} \mathrm{https}: / /$ www.sueddeutsche.de/digital/coronavirus-tracking-smartphone-app-ueberwachung-1.4869845

${ }^{21} \mathrm{https} / / / \mathrm{www} . w s j . c o m / a r t i c l e s /$ taiwan-and-the-virus-11584038158

${ }^{22} \mathrm{https} / / / \mathrm{www} . \mathrm{msn} . c 0 \mathrm{~m} / \mathrm{de}$-de/finanzen/top-stories/technologie-microsoft-startet-initiative-für-datenoffenheit/ar-

BB12YU9r?ocid=spartanntp\&fbclid=IwAR1zlzo05fJ5CA112kY0qgVzs0vkVgsS29_5uqgt1brO0ZDadDCQCScch60

${ }^{23} \mathrm{https} / / / \mathrm{www}$.apple.com/newsroom/2020/04/apple-and-google-partner-on-covid-19-contact-tracing-technology/

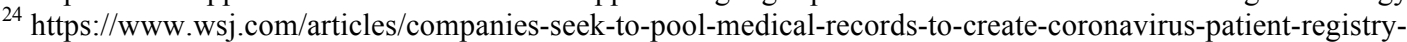

11586381102?shareToken=st988488c16b9e42289c06df0e23933e3f\&reflink=article_email_share

${ }^{25} \mathrm{https}: / /$ www.nytimes.com/2020/04/26/us/politics/trump-disinfectant-coronavirus.html

${ }^{26} \mathrm{https} / / / \mathrm{www}$.pepp-pt.org/content

https://www.economist.com/europe/2020/04/23/privacy-in-a-pandemic

${ }^{27} \mathrm{https} / /$ netzpolitik.org/2020/diese-regeln-plant-die-eu-fuer-daten-und-

algorithmen/?fbclid=IwAR0rH_NIxgBYvxzaDNrKLzUSV4tM2FnXVhHA8Bc-PTGYV8d7ETpxD7jL-TE

${ }^{28} \mathrm{https}$ ://ec.europa.eu/commission/presscorner/detail/en/IP_20_680

${ }^{29} \mathrm{https}: / /$ www.sueddeutsche.de/wirtschaft/pest-coronavirus-wirtschaft-1.4873813

${ }^{30} \mathrm{https}: / / \mathrm{www}$. thelancet.com/journals/lancet/article/PIIS0140-6736(18)30994-2/fulltext

${ }^{31} \mathrm{https}: / /$ data.worldbank.org/indicator/ny.gdp.pcap.cd

${ }^{32} \mathrm{https}: / /$ data.worldbank.org/indicator/it.net.user.zs

${ }^{33}$ www.transparency.org

${ }_{34}^{34}$ https://www.transparency.org/cpi2019?/news/feature/cpi-2019

${ }^{35} \mathrm{https}: / / \mathrm{www} . h$ uawei.com/minisite/gci/en/index.html

${ }^{36} \mathrm{https}: / / \mathrm{www}$. transparency.org/cpi2019?/news/feature/cpi-2019

${ }^{37} \mathrm{https} / / / \mathrm{www} . h$ uawei.com/minisite/gci/en/index.html

${ }^{38} \mathrm{https}: / / \mathrm{www}$. thelancet.com/journals/lancet/article/PIIS0140-6736(18)30994-2/fulltext

${ }^{39} \mathrm{https}: / / \mathrm{www}$. thelancet.com/journals/lancet/article/PIIS0140-6736(18)30994-2/fulltext

${ }^{40} \mathrm{http}: / /$ fold.it 